\title{
地震による崩壊の特徴とそのモデル斜面における理論的解析 一中国永登地震を例として一
}

\author{
Characteristics of Earthquake Induced Landslides and Theoretical Analysis on Model Slopes \\ - A case study on landslides due to the Youngdeng earthquake in China-
}

\author{
郎 煜 華* 中 村 浩 之* \\ Yu-Hua LANG \\ Hiroyuki NAKAMURA
}

\begin{abstract}
As a result of an investigation on landslides induced by the Yongdeng earthquake in China, 5 kinds of characteristics of landslides induced by the earthquake are summarized as following: a) they often occur in steep slopes from $30^{\circ}$ to $45^{\circ}, \mathrm{b}$ ) there are more landslides on convex slope than ones that on concave slope, c) failure surfaces are shallow, d) there are cracks on the upper slope of a landslide, e) landslides more concentrate around faults than the epicenter, etc. Each characteristics is explained theoretically by caulculation on model slopes using a limit equilibrium method of an application of dynamic programming to the Janbu's method which can search the critical slip surface under giving conditions. The influences of such factors as slope angle, slope type, the depth of surface layer, cohesions of surface layer and bedrock, horizontal and vertical seismic forces, are analyzed quantitatively.
\end{abstract}

キーワード: stability analysis, critical slip surface, seismic force

\section{1.はじめに}

地震による崩壊は降雨によるものとは異なり, いろい ろな特徵がある。例えば急斜面や凸型斜面に多発し，ま た表層崩壊が多く, 地震断層付近に集中的に分布するな どの特徴があげられる。これらに関し既にかなり多くの 報告がなされているが（例えば奥園 1980, 山口 1982, Jibson and Keefer 1988), これら崩壊の特徴についての 十分な説明がなされているとはいえない。このような崩 壊の形態的, 分布的な特徵と斜面構成材料の土質定数お よび震度との関係について検討することは重要な課題と 考えられる。そこで, 本研究ではまず中国永登地震によ り発生した崩壊の特徴について詳細に分析し, その特徴 をまとめた。次に, 動的計画法による臨界すべり面解析 により, モデル斜面における地震時の安全率とすべり面 の変化を分析し, 地震による崩壊の特徵を理論的に考察 した。

黄土高原に位置する甘肃省の過去の災害に関する 200 篇以上の歴史的文献について分析した。その結果地すべ り・崩壊, 洪水, 雹害, 虫害, 早害などを含めた全自然 災害の中で地すべり・崩壊災害は $29.0 \%$ を占めているこ とが明らかになった(郎, 1987)。地震は地すべり・崩壊を

* 東京農工大学
誘発する主要な誘因であり, 地すべり災害の中の $49.5 \%$ を占めるが, 降雨が少なく, 崩壊地形が長期間保存され ることから甘肃省は地震地すべりの研究の場として格好 の場所と考えられる（中村，1987 b : ZHU，1989； LANG, 1991)。

1995 年 7 月 22 日に中国蘭州市永登県に M 5.8 の地震 が発生した。現地調査を行った結果, この地震によって 150 箇所以上の崩壊が発生したが, 規模は小さいものが 多く, 崩壊が発生した斜面の勾配は急で, また, 崩壊が 凸型斜面に多発しているなどの特徴があることを確認し た（郎・中村, $1996 \mathrm{a}$ )。ところで植生状況についてみる とこの区域の年平均降水量は $350 \mathrm{~mm}$ であるとから，木 本類に欠き, 丈の短い草本だけが地表を被覆している。 また黄土高原に位置するこの区域の地質は, 数メートル から 40 メートルの厚さの黄土によって被覆され, 第三系 および白亜系の砂岩が基盤として分布している。このよ うに地被植生が少なく, 崩壊が単純な地層構造で比較的 狭い範囲に分布していることは，地震による崩壊の研究， 特に地震地すべりの特徴および影響要因の研究のフィー ルドとしては最適地と考えられる。 


\section{2. 崩壊の特徵}

\section{1 概況}

M 5.8 永登地震の震央の地理座標は北緯 $33^{\circ} 22^{\prime}$, 東経 $103^{\circ} 15^{\prime}$ であり, 震源の深さは $10 \mathrm{~km}$ である。この地震に よる人的被害は死者 10 人, 重傷 143 人, 軽傷 584 人で あった。また地震によって住宅が 2 万戸, 道路が 24 $\mathrm{km}$, 灌溉水路が $16.5 \mathrm{~km}$ などに被害があった。地震によ る直接的な経済損失は 1 億人民元以上と甘肃省政府は発 表している。

今回調查した地震による崩壊の分布を図ー 1 に示す。 図中の白丸は崩壊地点で, 不規則な線は河川をまた規則 的な線は等震度線を表す。白抜きの三角は集落である。 崩壊はほとんど震度VII（日本の震度階 Vに相当する）以 内に分布し，その分布範囲は $315 \mathrm{~km}^{2}$ である。中国にお いて震度VIIL上の範囲の面積と地震規模との関係（李, 1986）に関し非常に良い相関があると報告があるが，今 回の永登のデータをプロットすると, 両者の関係を満足 する平均的な值を示していることがわかった。

\section{2 地形的特徵}

崩壊地の斜面傾斜角の分布を図-2 の左半分に示す。 横軸は斜面傾斜角で, 縦軸は崩壞の占有率である。 $30^{\circ}$ か ら $39^{\circ}$ までの斜面が $67.3 \%$ を占め, $30^{\circ}$ より緩い斜面や

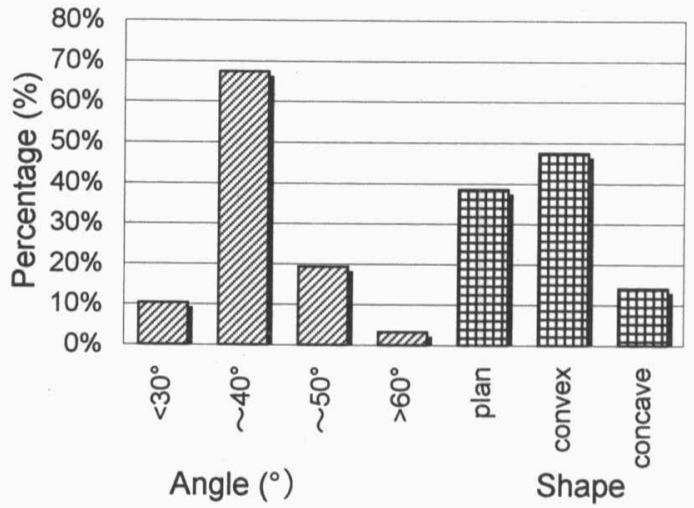

図ー2 地震による崩壊の傾斜角と形状の分布

Fig. 2 Distribution of slope angle and shape of earthquake induced landslide

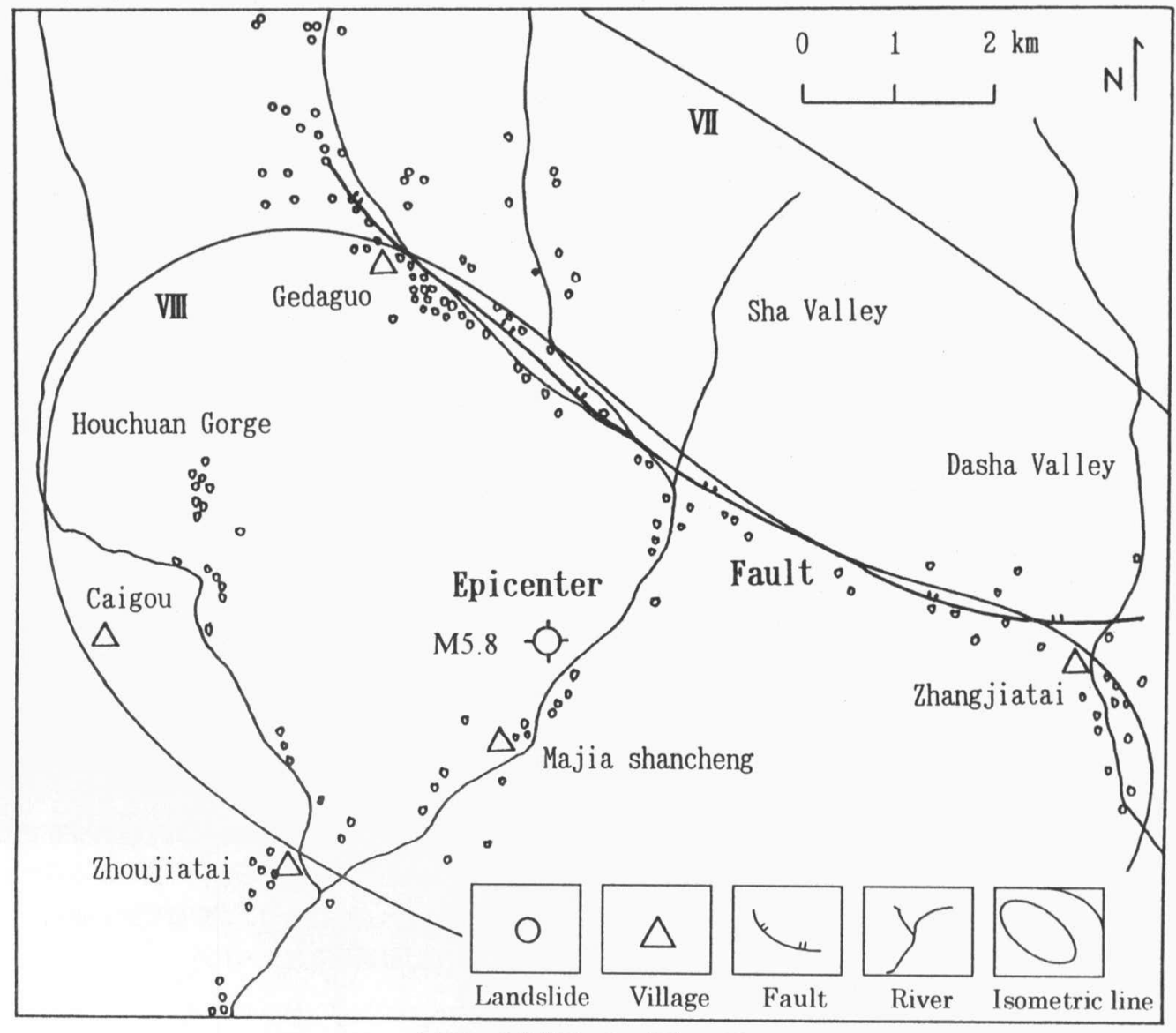

図一 1 永登地震による崩壊の分布

Fig. 1 Distribution of landslides induced by the Yongdeng earthquake 
$39^{\circ}$ より急な斜面における崩壊の数が少ない。これは緩 い斜面では安全度が高いために崩壊しにくく，また急な 斜面は基岩が露出した岩石斜面のため, 安定度が高いた めと思われる。

崩壊斜面における地形は凸型, 平行型, および凹型に 区別できる。図一2 の右半分は凸型, 平行型, 凹型の三種 類の斜面における崩壊の占有率を示している。横軸は左 から平行型, 凸型, 凹型の斜面形を示し, 縦軸はその斜 面における崩壊の占有率である。この図で明らかなよう に凸型斜面での崩壊が多く，凸型と平行型を合わせると 全体の $85.9 \%$ を占める。凹型斜面における崩壊の占有率 は $14.1 \%$ あるる。この地域における凹型斜面の大部分は 落水洞に関係するものと思われる。落水洞は降雨が黄土 の垂直節理に沿って形成される穴であり, 凹型斜面の中 下部に多く分布する。この黄土地区に特別な地形現象 (落 水洞）による崩壊を除ければ，凹型斜面における地震に よる崩壊の数はさらに少なくなると考えられる。

さらに地震によって発生する現象の一つとして, 斜面 に亀裂が多く発達するという特徵がある。亀裂は斜面上 部，とくに崩壊地の滑落崖の上部に分布し，より大きな 崩壊を引き起こす可能性を示す形態をとっている。永登 地震による亀裂は崩壊の集中地域に現れ, 崩壊地周辺の みならず斜面上部にも分布する。図一 3 にそれらの模式 図を示したが亀裂の延伸方向は二つの方向に分けられる。 一つの方向は尾根に沿って延伸するもので, その尾根の 両側斜面には崩壊が分布する。残りのものは崩壊地が拡 大するように分布するもので，崩壊地の周辺に存在する ものである。日本のように植生で覆われた斜面では亀裂

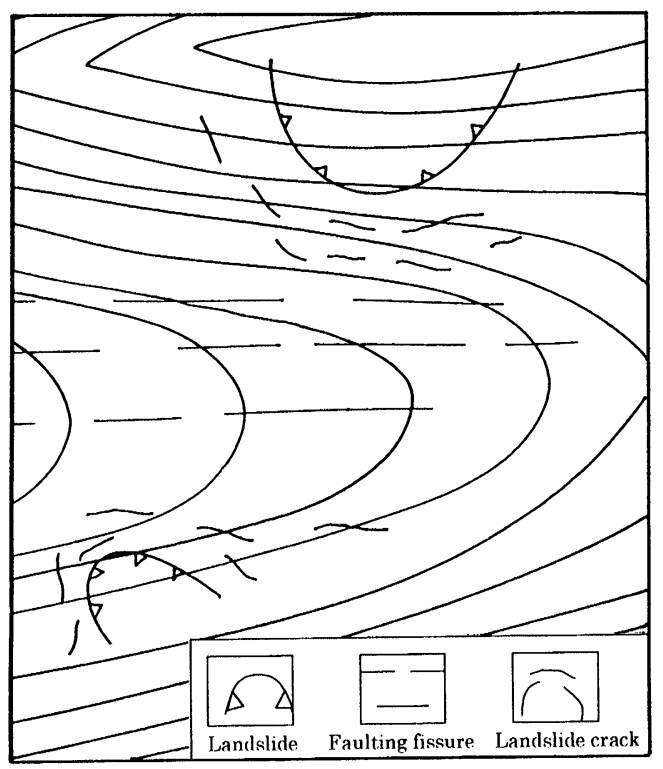

図ー3 崩壊による亀裂と断層亀裂の模式図

Fig. 3 Distribution of landslide cracks and faulting fissures
の分布は明瞭に分からないが, 亀裂の分布は斜面の安定 状況を示す重要な要因で, 地震による崩壊を研究すると きに無視することのできない存在であると考えられる。

以上地形的特徴をまとめると, 崩壊は急勾配斜面, 凸 型斜面に多発し, 崩壊地の周囲には亀裂が発達すること などが挙げられる。

\section{3 崩壊規模に関る特徵}

現地調查を実施し, 崩壊規模に関し長さ, 幅および厚 さなどを計測し，これを基に統計的分析を行い, その特 徵を検討した。崩壊地の長さ, 幅, および厚さの分布図 を図ー4に示す。これによると崩壊地の長さは短く, 約 $90 \%$ は $30 \mathrm{~m}$ 以下であり, また崩壊幅はほとんど $40 \mathrm{~m}$ 以 下である。崩壊厚さをみると $3 \mathrm{~m}$ より浅い崩壊の占有率 は全体の $94.9 \%$ あ゙あことが分かる。10 m を越えるよ うな深い崩壊は斜面末端部が河川の浸食により削られた 斜面のものであることより, 地震により発生する崩壊は そのほとんどが表層崩壊と考えられる。

\section{4 崩壊地分布の特徵}

地震による崩壊は地震断層沿いに集中的に分布する。 図一 5 は永登地震による崩壊の分布と地震断層からの距 離および震央からの距離との関係を示す。横軸は距離で, 縦軸は崩壊発生頻度である。崩壊は地震断層に沿って分 布し, 断層からの距離が近いほど崩壊の数は多い。全体 の $60 \%$ 以上の崩壊は地震断層から $1 \mathrm{~km}$ 以内に分布し, $4 \mathrm{~km}$ 以上離れたところに分布する崩壊は全体の $10 \%$ 以 下である。震度が小さい地震の場合には, 地震力の影響 範囲は狭く, 地震断層の近くだけ崩壊を誘発すると考え られる。

ところで地震による崩壊は震度が大きく, 被害の大き な震央に集中するとは限らない。図一 5 より伺えるよう に震央距離と崩壊地との関係をみると崩壊は震央に集中

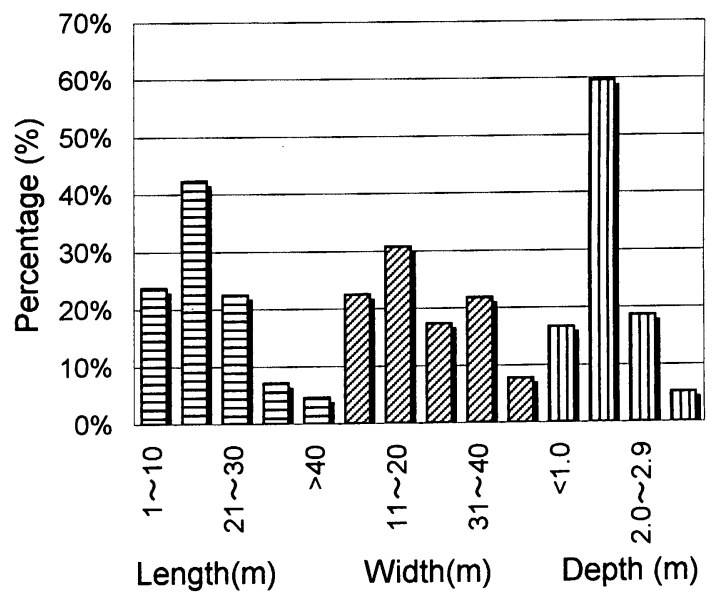

図-4 崩壊の長さ, 幅, と厚さの分布

Fig. 4 Features of length, width, and depth of landslides 


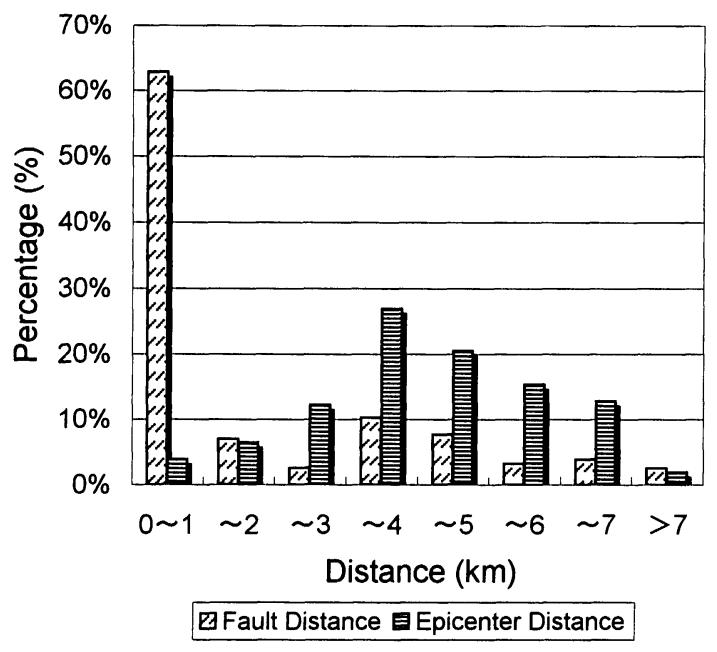

図-5 崩壊の断層距離と震央距離の分布特徵

Fig. 5 Distance between the fault, epicenter and landslides

せず, 崩壊の数は震央から $4 \mathrm{~km}$ の距離まで距離ととも に急速に增加し, そこでピークに達し，その距離を過ぎ ると徐々に滅少していくことが分かる。

このことより地震による崩壊は地震断層沿いに集中的 に分布し, 震央には必ずしも集中しない。この特徵は地 震による崩壊の発生メカニズムおよび発生筒所の予測に 重要な意味があると考えられる。

\section{3 . 安定計算による崩壊の解析}

\section{1 方法および条件}

地震による崩壊の特徴に影響を及沽す可能性のある因 子を選択し，モデル斜面を設定し，そこに関係する因子 を組み合わせ，臨界すべり面と安全率の変化を計算し， 地霞による崩壊の特徵を理論的に検討した。

本文におけるモデル斜面の安定解析は動的計画法によ る臨界すべり面解析法を用いた。この臨界すべり面解析 は与えられた地形，地質，土質条件等を基にして極限平 衡法の斜面安定解析法の一つである簡便 Janbu 法を用 いて, 最小安全率を持つ臨界すべり面を探索する方法で ある (中村等, 1987 a)。解析に必要なデー夕は, 斜面形 状および地盤構造, 地盤の単位体積重量およびせん断強 度定数と震度係数である。

地霞による地すべり・崩壊の発生に関係する要因につ いては，いままでに様々な角度から論じられている。例 えば Keefer (1984 a，1984 b) は 27 箇所の崩壊の発生源 における地質状態により，崩壊発生に深く関与する 5 種 類の素因を抽出したが，これらは斜面勾配，斜面高さ， 風化度, 土質, 侵食状況である。李（1986）は中国の地 霞による崩壊をまとめ，斜面勾配，岩石の種類および地

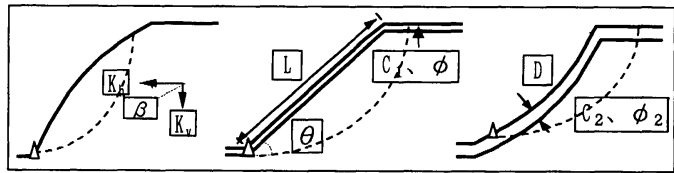

图ー6 モデル断面とその計算要素 $(\triangle$ : すべり面出口)

Fig. 6 Model slopes and calculation factors ( $\triangle$ : exit of slip surface)

\section{患-1 計算条件一覧表}

Table-1 Cases and conditions analysed

\begin{tabular}{|c|c|c|c|c|}
\hline No. & 要妻 & 記 昙 & 範囲 & ケース \\
\hline 1 & 縦横断 形状 & $Q, Z, P$ & 凸、平行、凹 & 3 \\
\hline 2 & 表層愿さ & D & $0,2,4 \mathrm{~m}$ & 3 \\
\hline 3 & 斜面長 & $\mathrm{L}$ & $10,50 \mathrm{~m}$ & 2 \\
\hline 4 & 斜面勾配 & $\theta$ & $30^{\circ}, 45^{\circ}$ & 2 \\
\hline 5 & 粘着力 & $\mathrm{C}$ & $0 \sim 5 \mathrm{tf} / \mathrm{m}^{2}$ & 11 \\
\hline 6 & 摩擦角 & $\phi$ & $30^{\circ}, 35^{\circ}$ & 2 \\
\hline 7 & 震度係 数 & $K_{v}, K_{h}$ & $0 \sim 1.0$ & 6 \\
\hline
\end{tabular}

下水深度の 3 種類の因子を地震地域の安定性を評価する 指標として提案した。吉松（1997）は地すべりの要因の 単相関およびファジィ相関を計算し，崩壊幅，崩壊長さ， 斜面形状, 高低差は崩壊の規模の推定に有意な要因であ ることを論証した。しかしこれらの論文のいずれも各因 子間の関係について特に定量的に論じているとはいえな い。本研究では地震による崩壊の特徴を考えて, 斜面に 関する 7 つの要因（縦横断形状, 表層土厚さ, 斜面長, 斜面勾配, 地盤の粘着力と内部摩擦角, 震度係数) を変 化させ，モデル斜面における臨界すべり面の比較計算を 行い，地震による崩壊発生に関する特徵に解釈を試みる ために，各因子の関係を分析した。図ー6 はモデル斜面の 断面と解析に用いる諸因子を図示し，また表一1にはそ の計算条件を示している。

凸型の斜面が地震により崩壊し易いことに関し多くの 報告がなされているが（安江・反町 1978，吉松 1990）， その理由についてはまだ明確な説明がなされていない。 同じ地質状況でかつ同じ長さの凸型，平行型，凹型斜面 の三ケースについて，その臨界すべり面および安全率を 計算し，地震により地形が受ける影響について検討した。

また地霞が地盤に与える影響を評価するために，表層 土と基盤が同じ材料からなる均質断面，表層土の厚さが $2 \mathrm{~m}, 4 \mathrm{~m}$ の断面を持つ斜面の三ケースについて臨界す べり面および最小安全率の比較計算を行った。均質断面 モデルは風化層が非常に薄い岩盤斜面を想定した断面で あり，表層土厚さ $2 \mathrm{~m}$ および $4 \mathrm{~m}$ の断面はそれぞれ異な る風化段階の表層土を持つ斜面を想定したものである。 
斜面規模による影響を評価するため，斜面長さについて $10 \mathrm{~m}, 50 \mathrm{~m}$ の 2 ケースを設定した。急勾配斜面特に $30^{\circ}$ から $45^{\circ}$ までの斜面に崩壊が多発するという特徵を考慮 し, 斜面勾配について $30^{\circ}$ と $45^{\circ}$ の 2 ケースについて臨 界すべり面の比較計算を行った。

郎・中村 (1996 b) によると，すべり面形状に最も影響 の大きい因子は地盤の粘着力であり, 地盤の内部摩擦角 は安全率に影響が大きいとの報告をしている。そこで本 研究では地盤の粘着力に着目し, また永登地区の調査結 果を踏まえてその值を $0 \mathrm{tf} / \mathrm{m}^{2}$ から $5 \mathrm{tf} / \mathrm{m}^{2}$ まで変化さ せ，その影響度合を検討した。また表層土の内部摩擦角 は $30^{\circ}, 35^{\circ}$ の 2 ケースについてその影響分析を行った。 斜面安定解析において, 地震力が斜面の安定度に与え る影響については数多くの研究がなされているが（例え ば，石原，1980；小林，1981；長尾哲，1982；Bromhead, 1988 ; Yeats, 1997), 水平地震力や垂直地震力が すべり面位置や斜面安全率に与える影響についてはあま り議論されていない。本文では水平震度係数および垂直 震度係数を 0 から 1.0 まで変化させ, 臨界すべりおよび 安全率の変化を計算した。

以下に地震による崩壊の特徴について，それぞれの解 析結果について述べる。

\section{2 斜面勾配と崩壊の発生}

地震による崩壊は急勾配斜面に多発する。特に斜面の 勾配が $30^{\circ}$ を超すと地震による崩壊が急増することより, 本文では勾配による影響を定量的に解析することを試み た。図ー7 は斜面勾配による影響の度合を示している。横 軸は震度係数で, 縦軸は斜面勾配 $45^{\circ}$ の斜面の安全率が 斜面勾配 $30^{\circ}$ の斜面の安全率よりどの程度低下するかを 示す係数 $\left(1-F_{45} / F_{30}\right)$ である。 $F_{45}$ は勾配 $45^{\circ}$ 斜面の安 全率, $F_{30}$ は勾配 $30^{\circ}$ 斜面の安全率である。 $30^{\circ}$ から $45^{\circ}$ ま

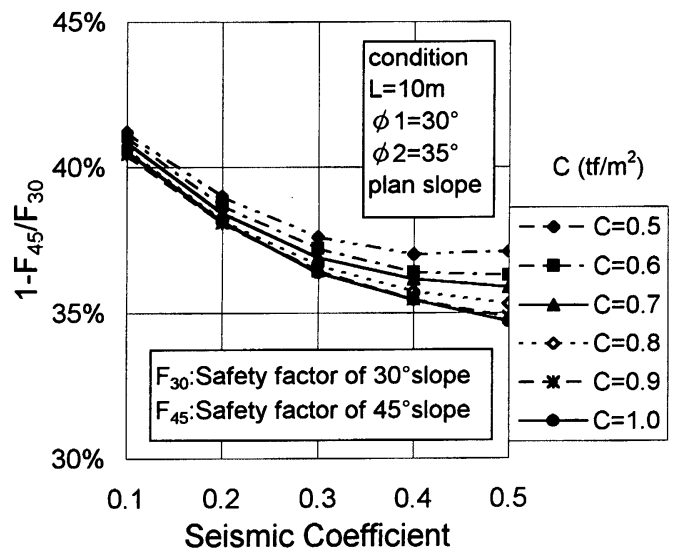

図-7 斜面勾配が斜面安全率に与える影響の度合

Fig. 7 The influence grade of slope angele on factor of safety
で勾配が 15 度変化することにより, 斜面の安全率は約 $34 \%$ ～ 2 \% 低下し, 平均的に約 38\%低下することがわか る。勾配が $1^{\circ}$ 急になることにより，斜面の安全率は約 $2.5 \%$ 低下するとも言える。

\section{3 斜面形状と崩壊の発生}

地震が崩壊発生に及ほすす地形形状，とくに凸型斜面に よる影響は従来地震波の増幅効果から議論されている （安江等，1981；Lawrence and West，1973)。本文では 地震時における地震波の斜面における増幅効果は無視し て，地形形状の影響だけを考え，すべり面および斜面安 全率の変化を検討した。崩壊斜面における地形は凸型, 平行型，および凹型に区別できる。地震による崩壊は凸 型斜面での崩壊は多いが，斜面の長さが短いほど凸型斜 面の安全率は小さくなり, より崩壊が発生し易くなるも のと推定される。縦横断形状とすべり面の関係について のモデル計算によると，均質土質の凸型および平行型斜 面のすべり面の出口はいずれも斜面下部の勾配変化点に 形成されるが，凹型斜面に拈いてはすべり面の出口は勾 配変化点より上部に形成される。また凸型斜面における すべりの滑落崖は斜面の中部から山頂までの間に形成さ れる。平行型および凹型斜面の滑落崖は全て斜面上部の 勾配変化点以上に形成される（図一6参照）。

各タイプの斜面に震度を変化させ，すべり面の位置に 与える影響を調べた。地震力が大きくなるとすべり面の 位置は少し深くなるが，すべり面の平均深さの変化は $5 \%$ 以下である。とくに凸型斜面の震度によるすべり面の 位置に与える影響は平行型, 凹型の斜面より少ない。

計算によると，凸型斜面での斜面の安全率は最も小さ く, 震度による安全率の低下度は最も大きいことが明ら かになった。すべてのモデル斜面に同じ粘着力 $c$, 内部摩 擦角 $\phi$ を適用して計算した結果によると, 凸型斜面にお ける臨界すべり面の安全率は最も小さく，平行型のもの の安全率は最も大きい。

地震による各タイプの斜面の安全率の低下度について, 凹型の安全率の低下度は最も小さい。一方，斜面勾配が 小さい時，平行型の斜面の安全率の低下度は大きいが， 勾配が大きくなるにつれ，凸型斜面の安全率の低下度は より大きくなっている。斜面勾配が大きくなるほど，ま た震度が大きくなるほど凸型斜面の安全率の低下度は大 きくなる。地震による安全率の低下度が大きな斜面形状 の順番は凸型 $>$ 平行型 $>$ 凹型である。

図ー8は地形形状による影響の度合いを示している。 横軸は震度係数で, 縦軸は平行型斜面の安全率より凸型 斜面の安全率の低下率 $\left(1-F_{q} / F_{z}\right)$ を示す。 $F_{q}$ は凸型斜 面の安全率で, $F_{z}$ は平行型斜面の安全率である。地形形 状による影響について主に地盤の粘着力の差によって安 全率の低下は 5\%〜 10\%に変化している。先に述べたよ 


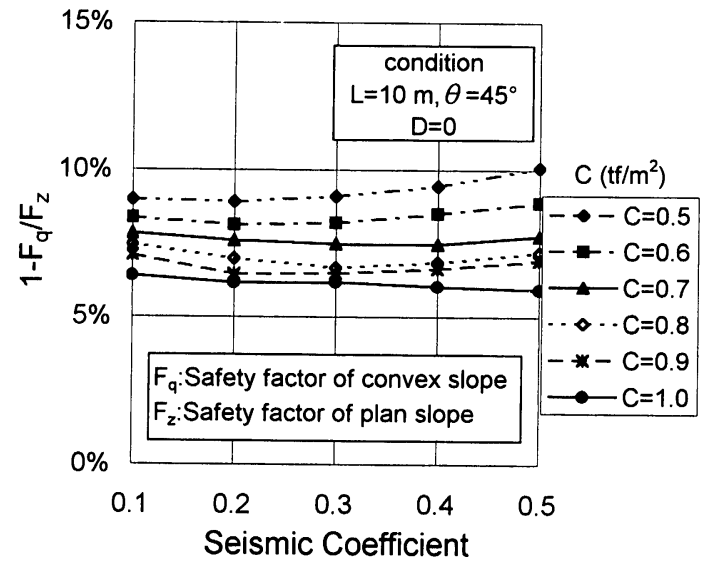

图-8 斜面形状が斜面安全率に与える影響の度合

Fig. 8 The influence grade of slope shape on factor of safety

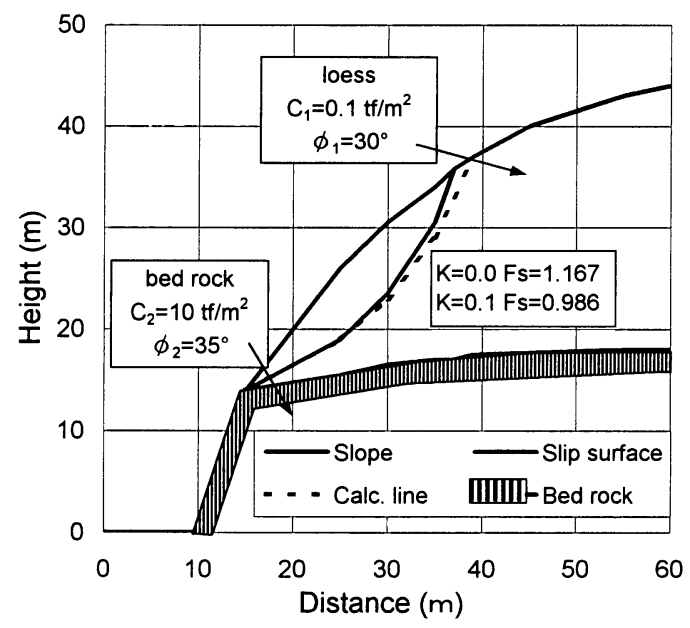

图ー9 黄土中のすべり面と計算すべり面

Fig. 9 Slide surface and calcalated one in loess

うに勾配 $1^{\circ}$ が $2.5 \%$ の安全率の低下になると換算する と，形状による影響は勾配の約 $2^{\circ}$ から $4^{\circ}$ ぐらいに相当 すると考えられる。地形形状による影響は斜面勾配によ る影響より小さいと思われる。

\section{4 地盤構成と崩壊の発生}

地震による崩壊の最大の特徴は表層崩壊の多発である。 今まで数多くの文献(例えば，中山，1988；釜井, 1989 ; 桑原，1979；小川，1997；川辺，1997）は表層崩壊の多 発を報告している。本文は臨界すべり面解析による計算 によって実際すべり面に近似するすべり面をトライアン ドエラーで探索し，すべり面の粘着力と内部摩擦角を理 論的に決定した。図-9 は実際の崩壊地の断面と計算に よって求められたすべり面の一例である。基岩の土質強 度定数は $c=10.0 \mathrm{tf} / \mathrm{m}^{2}, \phi=35^{\circ}$ で, 上部層の黄土の土質 強度定数が $c=0.1 \mathrm{tf} / \mathrm{m}^{2}$ で, $\phi=30^{\circ}$ であるとき, 計算す ベり面と実際すべり面は非常に良く一致し, 計算によっ

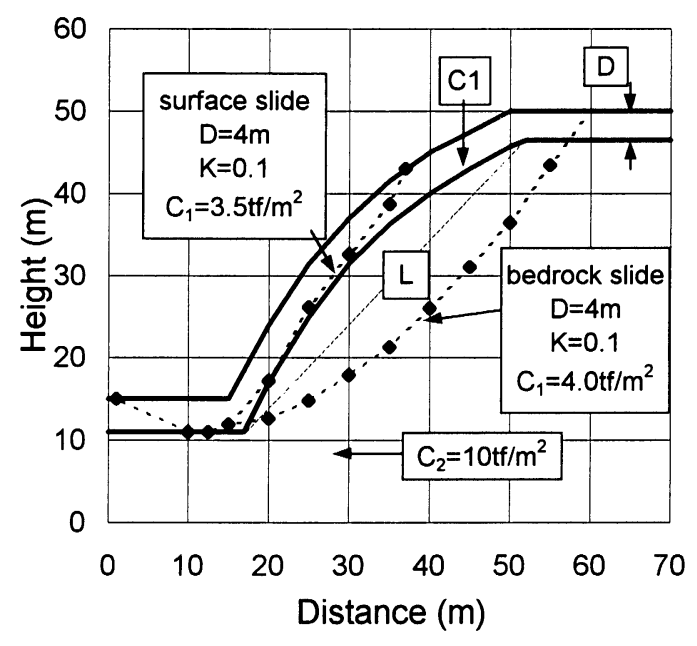

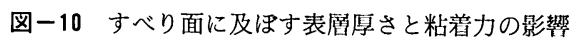

Fig. 10 Influence of the depth and cohesion on the shape of slip surfaces

て求められたすべり面は黄土と基盤の間に形成される。 即ちこの斜面では地震係数が 0 のとき安全率が 1.167 で, 地震係数が 0.1 のとき安全率は 0.986 となる。

モデル斜面における表層土層の厚さ $0 \mathrm{~m}, 2 \mathrm{~m}, 4 \mathrm{~m}$ の 三ケースで, 表層土の粘着力 $c$ は $0 \mathrm{tf} / \mathrm{m}^{2}$ から $10 \mathrm{tf} / \mathrm{m}^{2}$ まで, また震度を 0 から 1.0 まで変化させて, 臨界すべ り面に及ほす表層厚さと粘着力の影響について比較計算 を行った。ここで基盤の土質常数は $c$ が $10 \mathrm{tf} / \mathrm{m}^{2}$ で が $35^{\circ}$ である。

一般に斜面内に弱層が存在すれはそれがすべり面にな ることが多い。しかし, 地盤の粘着力あるいは震度係数 が大きくなると, すべり面は表層の厚さと関係なく基盤 まで達する深い崩壊になる傾向がある。即ち, 土質ある いは震度によって, 表層崩壊と基盤崩壊の二種類の崩壊 が形成されることになる。

図ー10 はすべり面に及ほす表層厚さと粘着力の影響 を示している。計算条件は凸型斜面, 表層厚さ $4 \mathrm{~m}$, 震度 係数 0.1 で，また基盤層の粘着力 $c_{2}$ は $10 \mathrm{tf} / \mathrm{m}^{2}$ である。 表層土の粘着力 $c_{1}$ が $3.5 \mathrm{tf} / \mathrm{m}^{2}$ のとき, すべり面は表層 土と基盤層の境界に沿って発達することが分かる。また 表層土の粘着力が $4.0 \mathrm{tf} / \mathrm{m}^{2}$ になると表層崩壊ではなく， 基盤崩壊になる。表層崩壊と基盤崩壊に分かれる条件を 調べるために, 形状比（崩壊厚 $D /$ 斜面長 $L$ ) と粘着力比 （表層粘着力/基盤層粘着力）を導入した。図－11 は斜面 の形状比と粘着力比による崩壊の分類を示す。横軸は形 状比で，縦軸は粘着力比である。プロットした点はその 条件での表層崩壊と基盤崩壊との変化点である。図の左 上部分は基盤崩壊になる領域で，右下部分は表層崩壊に なる領域である。横軸に注目すると, 形状比が 0.3 以上 になると全ての崩壊が表層崩壊になる。このことは表層 


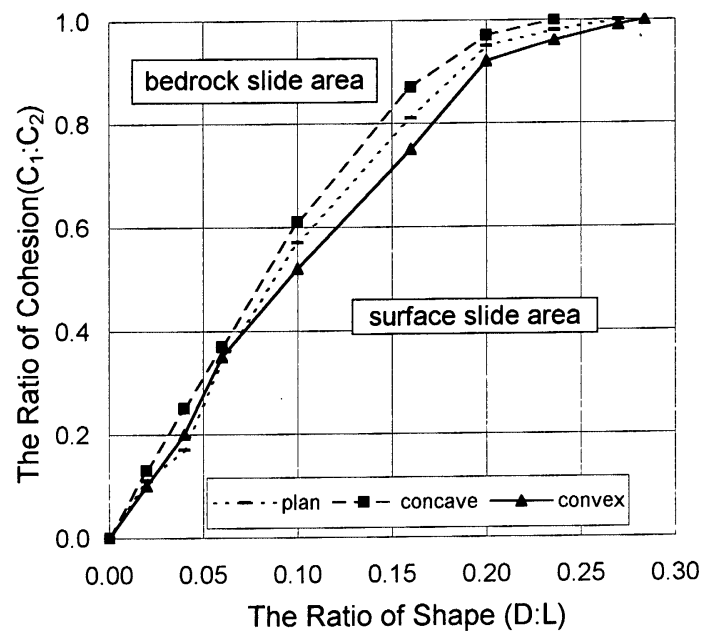

図-11 形状比と粘着力比による崩壊の分類

Fig. 11 Landslide classification by the relation between the ratio of shape and the ratio of cohesion

土層が厚く，粘着力が小さい場合には，地震力が小さく ても表層崩壊が発生することを意味する。

\section{5 地震と竜裂の発達}

地震による崩壊の滑落崖の上部に亀裂がしばしば発達 することが現場で観察される。これは地震時に斜面の安 全率が一時的に低下した結果であると思われる。

地震時には崩壊することはなかったものの, 龟裂が多 く発生し, 地震 3 ケ月後の降雨によってこれが大面積崩 壊に発展したとの事例が報告されている（陳・李 1978)。

図-12 は中国永登地震による崩壊の一例である。土質 常数を変化させ繰り返し計算をした結果, 実際のすべり 面と一致する臨界すべり面の土質常数は粘着力 $0.6 \mathrm{tf} /$ $\mathrm{m}^{2}$, 内部摩擦角 $30^{\circ}$ が得られた。実際に崩壊が発生し, 滑落したあとの斜面で新しい臨界すべり面を連続的に計 算した。図の実線は発生前の地表面線で, 破線はすべり 面である。点線は下部の斜面が滑落後の臨界すべり面で ある。a, b, …1 は実際に発生した亀裂の位置であり, 図の $F_{s a} \sim F_{s 1}$ は下部斜面が滑動したときの残存斜面の 臨界すべり面での安全率を示す。すなわち地震によって 斜面が滑落した後, 最小安全率となる臨界すべり面はb の所に形成される。しかし瞬間的な地震力による斜面の 安全率の低下はつぎつぎと上部斜面に進行するが，時間 経過とともに作用地震力が小さくなるにしたがって亀裂 は形成されるが滑りには至らないというような推論も可 能である。この様に臨界すべり面の滑落崖の上部に，連 続的に亀裂が形成され, その形成は最終的には斜面の地 震時安全率が 1.0 より大きいところで止まるものと考え られる。

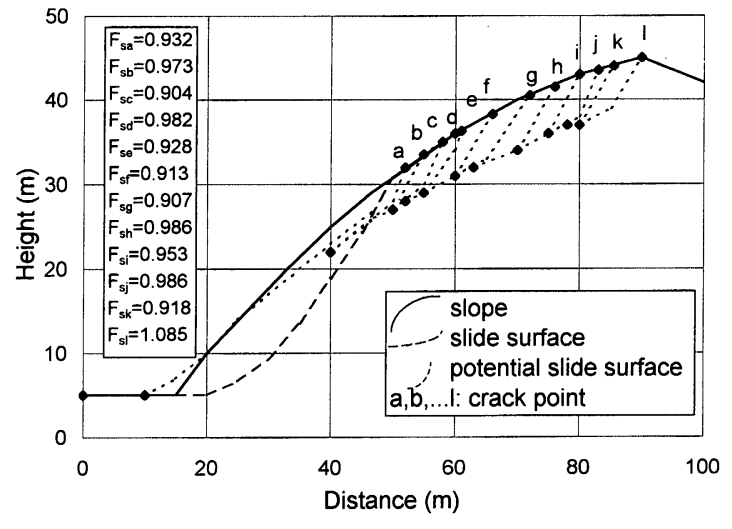

図一12地震による龟裂の発達過程

Fig. 12 The process of occurrence of seismic cracks

\section{6 崩壊と地震断層との関係}

地震による崩壊は地震断層の周辺斜面に集中し, 震央 に集中するとは限らないという特徵は, 地震力の分布お よび方向に関係するものと考えられる。地震力の分布と 崩壊との関係についていくつかの報告があるが，これに ついても明確な回答が得られていない。Newmark （1965）と Jibson and Keefer（1993）は地震断層の移動 量と崩壊の発生は相関し, 移動量がある限界に達したら 崩壊が発生すると論証している。S.Crampin（1991）と Y. G. Li（1994）は異なる地震波の伝達速度の差によっ てせん断応力は所々に大きく, 或いは小さくなる所があ ると論じた。

地震断層の移動が主に垂直運動のとき, 崩壊は地震で 直接誘発するされることはないが，その後の降雨或いは 地下水が原因で発生した例がいくつかある。例えば, 1976 年 5 月 29 日に中国雲南省における龍陵地震 (M 7.4) で は地震断層の移動は主に垂直移動で水平移動量はほとん どなく,この地震では直接誘発された崩壊は僅かであっ た（陳・李, 1978)。Tacoma 地震（1949, M 7.1）では 地震に直接誘発された崩壊はほとんどなかった。このと きの地震断層の移動は垂直移動であった。しかしこの地 震によって断崖の上に数センチの亀裂を引き起こし，3 日後地すべり $\left(8.0 \times 10^{5} \mathrm{~m}^{3}\right)$ が発生した（Chleborad・ Schuster, 1990)。

著者らは地震断層の移動距離と崩壊発生との関係を調 べるために中国炉霍地震 (1973，M 7.9) により発生した 崩壊に関する報告（王，1978；Lang and Nakamura， 1997） から, 地震断層の水平移動距離, 垂直移動距離お よび崩壊の分布を抽出し, それらの関係を検討した。こ の理由は地震断層周辺では地盤変位が大きく, 断層から 離れると変位量が小さくなり崩壊発生に与える影響は異 なるのではないかと考えたためである。一つの断層亀裂 
の影響範囲はその水平移動量と正の相関がある （Newmark，1965）と想定し，実測された断層亀裂の移 動距離との比例によって，その影響する範囲を区分し， この範囲内で存在する崩壊の数を数えた。合計六ケ所で 断層化裂の移動量が実測されており，6グループ地区で の崩壊を計測した。図ー13 は炉霍地震による崩壊の数と 移動量との関係を示す。縦軸は実測した地震断層の移動 量で, 横軸は崩壊数である。黒い三角 $(\mathbf{\Delta})$ は水平移動 量を, 白い四角（口）は垂直移動量を表す。点線は崩壊 数と水平移動量との関係を示す線であるが, 水平移動量 が大きくなると崩壊発生箇所数が増加する傾向があるこ とにより垂直移動量のそれよりも関係が深いと思われる。 垂直地震力や水平地震力の影響を調べるために，モデ ル計算を行った。図一14 は長さ $50 \mathrm{~m}$, 斜面勾配 $45^{\circ}$, 地 盤の粘着力 $5.0 \mathrm{tf} / \mathrm{m}^{2}$, 内部摩擦角 $30^{\circ}$ の均一な材料で形 成される凸型斜面における臨界すべり面および斜面の安 全率の変化を示したものである。左の二つの曲線は垂直 地震力 (Kv) だけを与えた条件で計算した臨界すべり面 であり，右の二つの曲線は水平地震力だけを考慮して計 算したものである。図から明らかなように水平地震力が 0.1 から 0.5 へ増大するにつれて, すべり面は若干深く なるが斜面の安全率は 1.14 から 0.65 に著しく低下する。 しかし垂直地震力の場合には臨界すべり面は僅かに浅く なり, また斜面の安全率の低下も 1.14 から 1.28 と変化 は少ない。このことにより斜面の安全率だけではなく， すべり面位置の変化に及注す影響にも水平地震力の関与 は大きいことが分かる。

図一 15 は長さ $50 \mathrm{~cm}$, 粘着力 $3.0 \mathrm{tf} / \mathrm{m}^{2}$ の均一な材料 で構成される凸型斜面において斜面の安全率が平常時の 1.0 から地震時にどの程度低下したのを示したものであ る。 $K_{v}$ は垂直地震力のみ, $K_{h}$ は水平地震力のみまた $K_{v h}$ は水平, 垂直の 2 成分を持つ地震である。 $K_{v h}$ は合成され 地震力でその大きさは $K_{v}, K_{h}$ と同じであり, $\beta$ は垂直地 震力と水平地震力の 2 成分を持つ地震力の方向と水平面 との間の角度であり, したがって $\beta$ が小さいほど水平地 震力の成分が大きくなる。図から明らかなように地震の 斜面安全率に対する影響は垂直地震力を受けた場合がー 番小さく，水平地震力の場合が一番大きいことが分かる。

\section{4.まとめ}

地震による崩壊の特徵をまとめ，モデル斜面における 地震時安全率とすべり面の変化を分析し，これらの特徵 を理論的に考察した。

急勾配斜面に崩壊が多発するという特徵について，勾 配による影響を議論し，勾配 $1^{\circ}$ の変化は約 $2.5 \%$ の斜面 安全率の低下を引き起こすことを明らかにした。

凸型斜面に崩壊が多発するという特徴について地形形

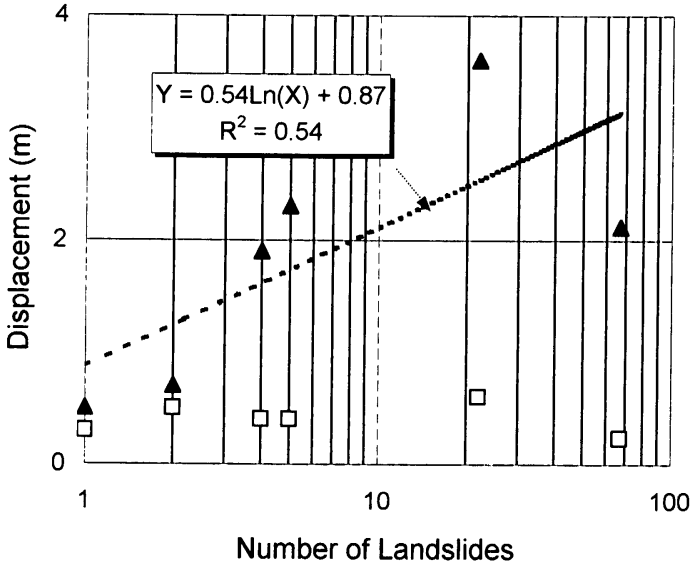

$\Delta$ Horizontal Displacement $\square$ Vertical Displacement

図ー13 断層移動量と崩壊数との関係

Fig. 13 Relation between displacement of a fault and number of landslides

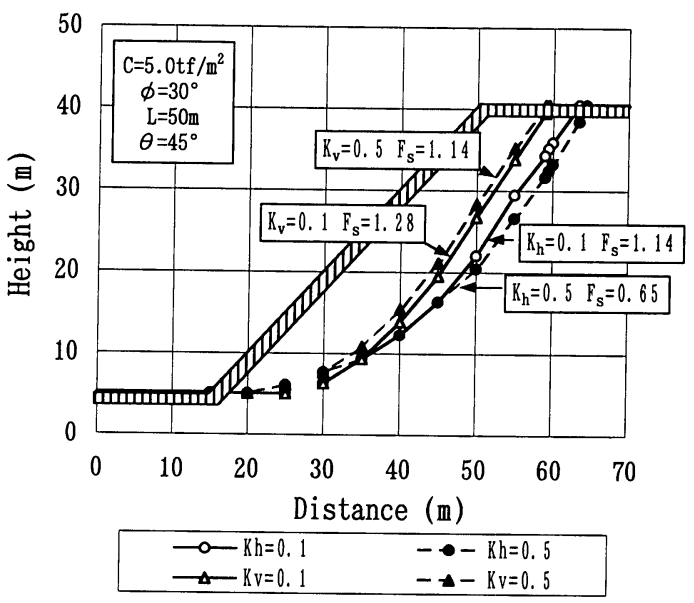

图ー14 すべり面と斜面安全率に及ぽす震度の影響

Fig. 14 Seismic influence on slide surfaces and the factor of safety

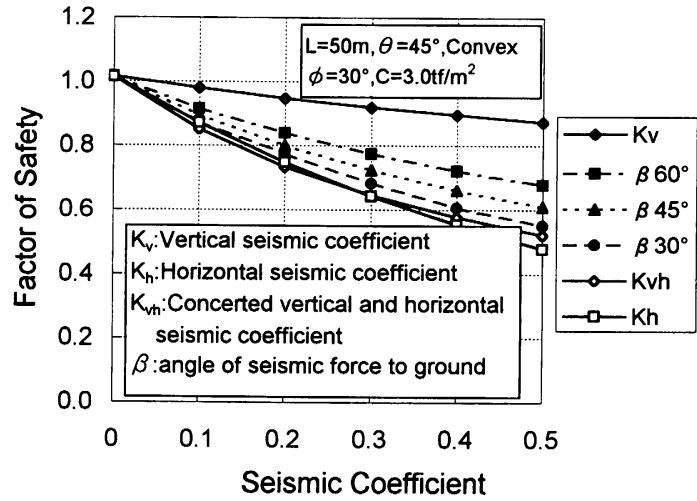

图一15 水平地震力および垂直地震力が斜面安全率に与える 影響

Fig. 15 Influence of the direction of the seismic force on factor of safety 
状による影響を議論し，凸型地形による影響は勾配の $2^{\circ}$ 〜 $4^{\circ}$ に相当し, 地形形状による影響は勾配による影響よ り小さいとの結論を得た。

表層崩壊が多発するという特徴については, 表層土の 厚さと地盤の粘着力による影響が大きいことを明らかに し，形状比および粘着力比の導入によって表層崩壊と基 盤崩壊に分かれる条件を示した。

地震時に斜面で亀裂が発達するという特徵については 二次元断面では崩壊地の滑落崖上部に拡大するものとし て解釈し，亀裂の位置および発生範囲を計算で検証した。 また地震による崩壊は地震断層に集中し, 地震力の大 きい震央に集中するとは限らないという特徵については 震央および断層沿いの地盤の変位や振動特性より, 地盤変 位量の大きい断層沿い地域が震度分布の中心となる震央周 辺地域より崩壊が多いのではないかということを推論した。 今後の課題として地震による崩壊の特徵を考慮し, 山 腹斜面における地震地すべりの発生可能性の評価, 崩土 の到達範囲のシミュレーションおよびその予測について 検討していきたい。

最後に本研究を実施するにあたつて現場調査でご協力 頂いた中国甘肃省科学院地質自然災害防治研究所の曽思 偉総工程師, 馮学才所長および王念秦研究員に心から御 礼申し上げます。

\section{参考文献}

Bromhead E. N. (1988): Strategies for the evaluation of seismic slope stability within the limit equilibrium method, ISL 1988, Editor C. Bonnard, A. Balkema, pp. 561-563.

Chleborad A. F. Schuster R. L. (1990): Ground failure associated with the Puget Sound region earthquakes of April 13, 1949 and April 29, 1965, U. S. Geol. Surv. Open -File Rept, pp. 90-687.

Crampin S. - Lovell J. H. (1991): A decade of shear-wave splitting in the Earth's crust:what does it mean? what use can we make of it? and what should we do next? Geophy. J. Int, Vol. 107, pp. 387-407.

Jibson R. W. Keefer D. K. (1993): Analysis of the seismic origin of landslides:examples from the New Madrid seismic zone, Geological Society of America Bulletin Vol. 105, pp. 521-536.

Jibson R. W. Keefer D. K. (1988): Statistical analysis of factors affecting landslide distribution in the New Madrid seismic zone, tennessee and Kentucky, Engineering Geology, Vol. 27, pp. 509-542.

Keefer D. K. (1984a): Landslides caused by earthquakes, Geological Society of America Bulletin, Vol. 95, pp. 406 -421 .

Keefer D. K. (1984): Rock avalanches caused by earthquakes: source characteristics, Science, Vol. 223, pp. $1288-1290$

LANG Yu-Hua (1991): Landslide disaster and monitoring network in Gansu, China, Japan-U. S. Workshop on Snow Avalanche, Landslide, Debris Flow Prediction and Control, Tsukuba, Japan, pp. 267-275.

LANG Yu-Hua -NAKAMURA Hiroyuki (1997): Influences of the horizontal and vertical seismic force on earthquake induced landslide, Journal of Gansu Sciences China, Vol. 9 Sum. No. 36, pp. 91-98.

Lawrence L. D. West L. R. (1973): Observed effects of topography on ground motion, Bulletin of the Seismological Society of America, Vol. 63, No. 1, pp. 283-293.

Li Yong-Gang •TENG Ta-Liang - Thomas. HENYEY, (1994): Shear-wave splitting observations in the Northern Los Angeles Basin, Southern California, Bulletin of the Seismological Society of America, Vol. 84, No. 2, pp. 307-323.

Newmark, N. M. (1965): Effects of earthquakes on dames and embankments. Geotechnique 15 (2), pp. 139-160.

Yeats R. S.•Sieh K.•Allen C.R. (1997): The geology of earthquakes, Oxford University Press, 568P.

ZHU Hai-Zhi, (1989): Some types of seismic landslides in loess area in China, Intern. Field Workshop on Loess Geomorphological Processes and Hazards, Journal of Lanzhou University, June, 1989, pp. 64-71.

安江朝光 -反町雄二 (1978): 地震と斜面崩壊について, 治水 と砂防, Vol. 11. No. 2, pp. 23-29.

安江朝光等 (1981): 斜面の地震応答特性の解析，土木技術資 料, Vol. 23, No. 4, pp. 191-244.

石原研而 (1980): 土構造物の耐震設計法の現状と問題点, 土 と基礎, 1980, 8, pp. 3-8.

奥園誠之・羽根田汎美・岩竹喜久磿（1980）：地震による斜面 崩壊の実態, 土と基礎, Vol. 28, No. 8, pp. 45-51.

沖村孝・梅本孝志 (1989): 地すべり規模に影響を及ほすす要因 の統計的研究, 建設工学研究所報告, No. 31, pp. 211-227.

小川紀一朗 (1997): 山地斜面における表土層の構造特性と水 分変動過程に関する研究, 北海道大学農学部演習林研究報 告, Vol. 54, No. 1., pp. 87-141.

王成華等 (1978): 炬霍地震地滑調査, 地震 と地滑, 中国成都山 地研究所, 成都, 中国, pp. 23-38.

釜井俊孝 (1989): 1987 年千葉県東方沖地震による上総丘陵の 斜面崩壊, 地すべり, Vol. 26, No. 1, pp. 16-25.

桑原啓三 (1979): 伊豆半島近海地震による斜面崩壊の実態, 応用地質, Vol. 20, No. 1, pp. 21-28.

川辺洋・辻本文武・林拙郎 (1997): 兵庫県南部地震による六 甲山地の崩壊分布, 砂防学会誌, Vol. 49, No. 5, pp. 12-19.

小林芳正 (1981): 地震による二三の斜面崩壊の解釈, 京都大 学防災研究所年報, No. 24 B-1, pp. 401-410.

山口伊佐夫・川辺洋 (1982)：地震による山地災害の特徵, 新 砂防, Vol. 35, No. 2 pp. 3-15.

中村浩之等 (1987 a): 動的計画法を用いた臨界すべり面解析 法, 土木研究所資料, 第 2425 号, pp. 1-69.

中村浩之 $(1987 \mathrm{~b})$ : 中国甘肃省の地すべり・土石流災害, 地す ベり技術, Vol. 14, No. 1, pp. 18-25.

中山康 (1988): 千葉県東方沖地震による斜面崩壊, 地すべり, Vol. 24, No. 4, pp. 33-35.

長尾哲 (1982): 斜面の土の動的強度と安定解析, 地すべり技 術, Vol. 9, No. 2, pp. 6-9.

吉松弘行・黒川邦夫（1997）: GA を用いたファジィ推論法に よるすべり面深度の予測, 地すべり, Vol. 33, No. 4, pp. 8-13.

吉松弘行 (1990): 千葉県東方沖地震による斜面崩壊地調查, 土木研究所資料, No. 2824, pp. 1-149.

陳福斌・李鐘武 (1978): 龍陵地震地滑調査, 地震と地滑, 中国 成都山地研究所, 成都, 中国, pp. 53-88.

李天池等 (1986): 地震与地滑的関係及地震地滑予測的探討, 地滑文集・第二集, 人民鉄道出版社, 北京, 中国, pp. 127-132.

郎煜華 (1987): 甘肃省歴代地滑簡析, 地滑文集, 四川科学技術 出版社, pp. 77-81.

郎显華・中村浩之 (1996 a)：中国蘭州市永登 M 5.8 地震によ る崩壊の特徵, 第 35 回地すべり学会研究発表講演集, pp. $31-34$.

郎煜華・中村浩之 (1996b): 再活動型地すべりおよび初生地 すべりの地震時安全率の変化, 平成 8 年度砂防学会研究発 表概要集, pp. 51-52. （原稿受理日 平成 9 年 6 月 25 日） 
飽和度の上昇に伴う不飽和砂質土のせん断变形機構に関する研究

「地すべり」Vol. 34, No. 3 (通巻第 131 号) pp. 1 8, 1997 年（平成 9 年）12 月

笹原克夫

不飽和砂質土のサクション除荷に伴うせん断変形機構について検討するため., 不飽和三軸圧縮試験装置を用い たサクション除荷試験を行った。その結果サクション除荷に伴うせん断進行が確認できると共に, 主応力比及び 平均主応力の変化がせん断進行に与える影響についても定量的に評価できた。次にサクション除荷に伴うせん断 変形の進行を予測するための, 不飽和砂質土の構成式を提案した。これはサクションに起因する等方的なボンド 応力で応力を補正し，その後松岡の提案した CMP 上で応力・ひずみ関係を定義するものである。このモデルはサ クション除荷試験でのひずみの進行をよく再現できた。

仙台市内における先デボン紀層と温泉の新発見および地すべりとの関連について

「地すべり」Vol. 34, No. 3 (通巻第 131 号) pp. 9 16, 1997 年（平成 9 年）12 月

盛合禧夫, 上野春雄

仙台付近には第三系しか分布しておらず，地下は全く不明であった。1996 年 10 月 1 日仙台市内で $1200 \mathrm{~m}$ の試 錐を行って先デボン紀層と $58^{\circ} \mathrm{C}$ 温泉を発見した。何れも従来まで知られていない新事実であった。この事実か ら，仙台付近の地質構造が明確になり，地すべりとの関連も解明でき，同時に地震発生についても大きな手がか りとなった。

1995 年兵庫県南部地震時に発生した六甲花崗岩地域の斜面崩壊の運動様式と機構

「地すべり」Vol. 34, No. 3 (通巻第 131 号) pp. 17 24，1997 年（平成 9 年）12月

横山俊治, 菊山浩喜

兵庫県南部地震で発生した六甲花南岩の斜面崩壊は地震動加速度の慣性力による転倒が発生時の運動様式であ

る。崩壊発生頻度は新鮮で割れ目の少ない花崗岩や尾根上の花崗岩巨鿬で高い。

地霞による崩壊の特徵と光のモデル斜面における理論的解析

一中国永登地霞を例として一

「地すべり」Vol. 34, No. 3 (通巻第 131 号) pp. 25〜33，1997 年（平成 9 年）12月

郎 暲華, 中村浩之

地震による崩壊はいろいろな特徴がある。例えば急斜面や凸型斜面に多発し，また表層崩壊が多く，地震断層 付近に集中的に分布するなどの特徴があげられる。本研究では中国永登地霞により発生した崩壊の特徴について 詳細に分析し，その特徵をまとめた。次に，動的計画法による臨界すべり面解析により，モデル斜面にるける地 震時の安全率とすべり面の変化を分析し，地震による崩壊の特徴を理論的に考察した。

進行性破壊を考慮した斜面安定解析

「地すべり」Vol. 34, No. 3 (通巻第 131 号) pp. 34〜40, 1997 年（平成 9 年）12 月

滝 昌和, 山上拓男

極限釣り合い法に基づき進行性破壊を考慮した斜面安定解析法を開発した。進行性破壊は，スライス底面ごと に局所安全率を定義することで表現した。これにより未知量が大幅に増加するが，簡単な仮定を導入して問題を 静定化し，カとモーメントの釣り合い条件を完全に満足した。さらに，この局所安全率を用いて土の軟化現象を 考慮することができた。最後に，実際の崩壊事例に適用して本解析法が進行性破壞を表現し得ることを明らかに した。

三郡変成帯で発生した地すべりについて

一山口県宇部市の例 -

「地すべり」Vol. 34, No. 3 (通巻第 131 号) pp. 41〜50, 1997 年（平成 9 年） 12 月 山本哲朗, 瀬原洋一, 中森克己, 森岡研三

山口県宇部市における三郡変成岩からなる丘陵地の斜面で発生した地すべりの特徴を明らかにするために，地 質学・岩石学・土質工学の立場から斜面の調查を行った。その結果, 斜面地盤は蛇紋岩のホルンフェルス, 透角 閃石岩の破砕片と風化土が互層をなす透水性が比較的高いことが素因となり，また斜面末端部の切取りと豪雨が 誘因となって，地すべりが発生したと判断された。地すべり面の緑泥石からなる粘土の不擋乱試料の残留強度は， 通常の逆算法で求めた值と一致した。最後にスケンプトンの残留係数を用いてすべりの発生機構を考察した。 